\title{
A Need Analysis of English for Academic Purposes
}

\author{
Khoirul Anwar \\ English Language Education Department \\ University of Muhammadiyah Gresik \\ khoirulanwar@umg.ac.id
}

\begin{abstract}
The English for Academic Purposes (EAP) learning is shifting where some tend to lead to the English for General Academic Purpose (EGAP) and others lead to English for Specific Academic Purposes (ESAP). This shift towards two different poles is often due to the highly dynamic and numerous needs of the learners' character themselves so that the scope of EAP becomes highly developed and varied. This research seeks to explore and develop the diversity of new EAP needs based on mobile assisted language learning technologies. Using questionnaires to 40 students and interviews of 8 teachers in law, industrial, and education faculty, it was found that English proficiency of the participants was preintermediate $(78 \%)$ with the expected ability of speaking $(83 \%)$, and the scope of the material leads to success study and work. Learning materials refer to books and research articles that often come into contact with seminars and publications of scientific papers in the field of law, industrial and education with a combination of audio visual learning media and the integration of information technology (mobile assisted language learning) so as to facilitate the implementation of student learning center. Thus, these findings indicate that EAP trends are expected to be integrated with information technology (based on android), tend to lead to English for Specific Academic Purposes.
\end{abstract}

Keywords: Need analysis, English for Academic Purposes

\section{INTRODUCTION}

The implementation of English for Specific Purpose (ESP) often has many obstacles, especially in the difficulty of adjusting the expectations of learners, educational authorities, and ESP learning objectives [1]. These problems often arise because ESP has specific characteristics that may not be the same as English for General Purposes (EGP) [2].

Need analysis, in this case, is very strategic and has always been an important step in starting the English for Specific Purpose design [3]. Generally, this process always begins with an assessment of a focus on the learner and also other relevant parties who become the main responsibility of the learning process that will take place. All sides of the assessments should be wellidentified so that the conformity of the process and the materials to be delivered really satisfy the expectations of the stakeholders [4].

Need analysis is divided into two parts: goal-oriented and process-oriented assessment [5]. The identification of these objective-oriented needs is often related to what the learners need regarding their level or ability, the required contents, as well as its depth and breadth scopes. While process-oriented is often associated with the pattern and learning process during the course of ESP. The scope of this process orientation is identical to the methods and techniques of learning, media, atmosphere, and the desired evaluation system. Overall need analysis is identical with two similar categories: target needs and learning needs [1]. Thus, although Widdowson and Hutchinson have different terms in need analysis, they essentially lead to the same goal.

More explicitly Berwick states that the essential need analysis is the process of identifying gaps or differences between what is learned and what should be studied [6]. Often the identification of needs requires precision because each analyst has an influence on his or her findings and the subjectivity of the researcher that somewhat affects the findings of needs analysis [7].

Based on the learning objectives themselves, the needs can be clarified more deeply into goals that are individual and social. Therefore, Alderson translates this goal-based of need into four main points [8]: formal needs, actual need, future needs, and learner's own expectations. These four important points are also summarized into two major needs, namely the needs related to social aspects and those related to the educational aspect [9]. At implementation level, analysis of needs can also be divided into two important things, namely the objective needs and affective needs [10].

Therefore, this study aims to identify the learning needs of English for specific purposes at university level. Need analysis is of course to prepare the materials, methods, media, and evaluation of the learning required today where the learner is more reacting in the development of technology 4.0, the era where learning English should also promote the development of modern information technology such as e -learning based on online computer and also based on Android.

\section{METHOD}

The purpose of this study aims to identify an assessment of the English learning needs for students who pursue the ESP program existing at two universities namely 
Muhammadiyah Gresik and Ronggolawe Tuban universities. Considering the purpose of this descriptive analytical study, this study uses quantitative and qualitative design or mix method [11].

The subjects and data sources in this research are 40 (forty) students and 8 (eight) lecturers from two universities namely Muhammadiyah Gresik and Ronggolawe Tuban, where the two institutions are offeringESP for students.

Thus the research instrument in this study is an open and closed questionnaire containing items of questions about target needs as well as learning needs [12]. The questionnaire and interviewaredeveloped into 20 (twenty) open-ended questions.

The two instruments are checked their validity againsttheoriesreferring the essence of need analysis itself (the theory of Hutchinson and Waters and Robinson et al.).

After the data is collected, the analysis is performed by mapping quantitative and qualitative combinations into a finding description as a draft which is then used to be a prototype for the developed ESP materials.

\section{RESULTS}

Need analysis for students was conducted on 40 (forty) students from two institutions namely the study program of law, industrial and education from two universities namely Muhammadiyah Gresik University and RonggolaweTuban University. Their English proficiency in general is in post elementary position $(55 \%)$ and pre intermediate $(23 \%)$, the rest spread to elementary and intermediate. In particular the purpose of their English learning is to succeed study and also for a career at work (68\%). Speaking (83\%) is an English skill that they want to master and yet their speaking frequency is sometimes (49\%) almost never (32\%), meaning there is still a gap between high expectations and true language skills where they often talk to friends (24\%) and teachers (46\%) and to both $(29 \%)$.

In terms of reading, their reading sources are books $(78 \%)$, journals $(7 \%)$, and both are sources of reading from two sources of books and journals for reading at once $(15 \%)$. While the frequency of writing is still very rare $(24 \%)$, rarely $(39 \%)$, quite often $(32 \%)$, often $(5 \%)$. They often write letters $(50 \%)$, articles $(19 \%)$ and often write for both purposes is $31 \%$.

In terms of listening, the students stated very often $(1 \%)$, very often $(8 \%)$, rarely $(53 \%)$, very rare $(29 \%)$, and almost never $(8 \%)$. Generally speaking, they listen to the material in the form of English movie(42\%), English television $(11 \%)$, and always hear both tv and movie at once by $50 \%$.

Furthermore, in terms of their preferred learning method is by optimizing information technology (39\%), positive discussion and interaction accompanied (16\%), and through discussion only $5 \%$, and those who combine all $39 \%$.

Students also expect that the areas of work expected during and after training in English are industry, business and service (18\%), academic and education (42\%), and aiming for both purposes for academic and industrial interests $39 \%$.

In terms of future expectations and future English use, students state that English will be used in discussions and seminars $(32 \%)$, reading and writing journal articles, research reports, letters and books (5\%), communications with friends and colleagues (8\%), and who expect a combination of them all is $55 \%$.

In terms of the interest of learning English, students have a tendency to learn English by watching TV and movies (30\%), listening to music and radio (14\%) traveling and social culture $(19 \%)$ reading $(3 \%)$, and interested to all these interests is $35 \%$.

The results of the students' needs analysis above show that they have various target requirementswhich mainly for pre intermediate course. Similarly, their learning needs are closely related to specific academic courses.

\section{Results of needs from Lectures}

This section presents the findings of the need analysis of teachers from the closed and open questionnaires and interviews to eight lecturers at two universities, the faculty of law and industrial of the University of Muhammadiyah Gresik and the faculty of Teacher Training and Education of Ronggolawe Tuban University. There are seven things that become the focus of data collection in the analysis of this requirement that is the profile of student graduates, the purpose of learning English, the scope of English learning materials, appropriate learning methods, learning media needed, study materials that require English language, and general advice for learning English.

With regard to the profile of graduates, for the course of law study, the profile of graduates produced are diplomats, entrepreneurs and Entrepreneurship, and international law. While the graduate profile for the field of education is a professional educator who is competent with the mastery of English as an international language.

While the objectives of English learning in the course of law science and industrial engineering include the purpose of strengthening the ideal graduate profile (13\%), supporting the scientific mastery of the study program and simultaneously strengthening the graduate profile $(88 \%)$.

Next is related to the scope of the material in English learning where English material must be in accordance with the basic courses in the study program $(25 \%)$ as well as a mixture of general English language material and simultaneously in accordance with the basic courses in the study program $(75 \%)$.

The learning method of English in accordance with the study program is communicative learning (13\%), a combination of lecture method, student-centered, and communicative method $(88 \%)$.

Based on the findings, the required and effective learning media is a combination of Android-based media, computer-assisted media, and audio visual (100\%).

The next section is an overview of study materials and material coverage requiring English competency. The fields of law science include the integration of reading, writing, listening, and speaking, international 
law and comparative law, and mass communication. Industrial engineering include English for industry, industry management, and large, medium and small industry governance.

Overall suggestions include the need for increasing the number of credits, focusing on the habits of oral and written communications rather than grammar, the importance of conversational video tutorials and easy English pronunciation tutorials, applied English, intensive coordination between English teachers and lecturers studying in study program.

Research focusing on need analysis has also been largely done by ESP designers such as Christison and Krahnke identifying teacher beliefs as part of needs including desirable English skills, learning experiences, as well as learners' opinions on their teachers [13]. The same pattern of need analysis is also used by Clowes who focuses on the learning needs in the industrial world where perceptions and use of language functions are used and the reasons behind their opinions [14]. Likewise Howells against the learners of China [15] and Jordan is about the difficulties of overseas students in UK [16]. All of them have used questionnaires and interviews in identifying all learning needs of learners and stakeholders that can be used as the desired ESP learning materials [2]. All research on need analysis shows that: (1) Need analysis becomes the first step in providing opportunities for the formation of material that is always in accordance with the purpose of learning English with a specific purpose. (2) Each requirement analysis has a unique and specific characteristics that describe the learner's information and the needs as a whole, therefore it is unlikely that the findings of each need can be generalized to other needs. (3). Need analysis is always needed because the needs of the learners is very dynamic so it must be done periodically and continuously by each learning designer and teacher or lecturer especially in the field of ESP.

\section{CONCLUSION}

This need analysis concludes that the English language ability of the learners is in the post elementary or pre intermediate position where the speaking ability is expected to optimize predominantly. Learning English is expected to encourage the achievement of success in the study and also the work. So that the desired English learning materials are related to books, research articles etc. that can be disseminated in seminars and other scientific societies. All materials are expected to be presented by combining the development of information technology, especially mobile assisted language learning technology to facilitate the achievement of studentcentered learning implementation.

This research also sharpens that EAP in the present context is more likely to be closer to meeting the needs of learners leading to English for specific academic purposes and not English for general academic purposes. This trend is predicted to continue as the differences in the development needs of learners are very dynamic in accordance with the demands of the rapid development of modern culture.

\section{REFERENCES}

[1] Hutchinson and Waters, English For Specific Purposes, NY: Cambridge University Press, 1987.

[2] C. H. Asmara, K. Anwar and M. Ribeh, "EFL Learners' Perception toward an Outdoor Learning Program," International Journal of Education \& Literacy Studies, vol. 4, no. 2, 2016.

[3] G. Conole, Designing for Learning in an Open World, New York: Springer, 2013.

[4] G. D. Kuh, "'What student affairs professionals need to know about student engagement'," Journal of College Student Development, vol. 50, no. 6, pp. 683-706, 2009.

[5] H. Widdowson, English for Specific Purposes:Criteria for Course Design, in L. Selinker at.al. (Eds), English for Academic and Technical Purposes: Studies in Honor of Louid Trimble, pp III, London: New Bury House, 1981.

[6] R. Berwick, Need Assessment; Language Programming: From Theory to Practice. In R.K Johnson (eds), The Second Language Curriculum, pp 48-62, NY: Cambridge University Press, 1989.

[7] P. Robinson, ESP Today, New York: Cambridge University Press, 1991.

[8] J. Alderson, "A Process Approach of Reading at The UNiversity of Mexico_Project in Material Design," ELT Documents Special, pp. 134-163, 1980.

[9] N. Kharma, "ELF and Community Needs," IRAL, International Review of Applied Linguistics. XXXVI, vol. I, pp. 49-67, 1988.

[10] C. Brindley, "The Role of Needs Analysis in Adult ESL Programme Design.," The Second Language Curriculum, pp. 63-78, 1989.

[11] K. Anwar, "A Constructive Teaching Model in Learning Research Concept for English Language Teaching Students," International Education Studies, vol. 8, no. 5, 2015.

[12] K. Anwar and Y. Arifani, "Task Based Language Teaching: Development of CALL," International Education Studies, Vols. Vol. 9,, no. No. 6., 2016.

[13] M. Christinson and K. Krahnke, "Student Perception of Academic Language Study," TESOL Quarterly, vol. 20, no. 1, pp. 61-79, 1986.

[14] P. Clowes, "Learning What are The Language Needs of Industry?," Language Journal, vol. 9, pp. 22-25, 1994.

[15] F. Howell, "Chinese Language Learning: Student Needs and Expectations: A Case Study," Babel, vol. 30, no. 2, pp. 22-27, 1995.

[16] R. Jordan, "Study Skills: Experience and Expectations," in Learng and Success: Studying Through English, London, Macmillion, 1993. 